\title{
Video-monitoring helps to optimize the rescue of second-hatched chicks in the endangered Bearded Vulture Gypaetus barbatus
}

\author{
ANTONI MARGALIDA, DIEGO GARCÍA, RAFAEL HEREDIA and \\ JOAN BERTRAN
}

\begin{abstract}
Summary
From 2000-2008 we used transmitting video cameras to document the breeding biology of the endangered Bearded Vulture in the Pyrenees (NE Spain), focusing the study on sibling aggression. Our goals were to study the feasibility of rescuing second-hatched chicks for conservation purposes in this species that shows obligate brood reduction. The age at which the second chick died varied between 4 and 9 days $(n=5)$. Prey items delivered per hour were not related to the survival time of the second chick or the aggressiveness of the first-hatched chick towards their sibling. Although sibling aggression generally began on day 1 after hatching, in two nests supplemented with food, aggression was delayed until the second and third day after hatching and the second chick survived for nine days. Our results on the death of the second chick and the test involving the rescuing of a second-hatched chick aged five days, suggest that the recommended age for intervention should be between 3 and 6 days, with $4-5$ days probably being the optimal age for the rescue.
\end{abstract}

\section{Introduction}

Conservation projects for endangered species are principally based on enhancing habitat, providing artificial nest sites, increasing food availability and controlling predators and pathogens (Jones 2004). Another, less frequently used conservation tool is based on increasing productivity in breeding birds through clutch and brood manipulations. In species that normally lay two eggs but where only one young usually survives as a result of sibling aggression, the surplus eggs have been harvested for captive rearing (Kepler 1978). On other occasions the young have been removed to increase productivity, both in facultatively siblicidal (Meyburg 1978, Watson et al. 1996, Cade 2000) and obligate siblicidal species (Gargett 1990) considered those in which more than $90 \%$ of last-hatched chicks die (Simmons 1988).

In raptors, brood reduction is influenced by both size differences between chicks and by food availability (e.g., Edwards and Collopy 1983, Bortolotti 1986). In several facultatively siblicidal species it has been documented that supplementary feeding during the nestling period increases fledging success (see González et al. 2006) and the aggression of dominant brood members intensifies with food deprivation. However, in obligate siblicidal species in which older chicks kill their younger sibling (Anderson 1990) it has been proposed that aggressiveness is not related to food availability (Forbes and Mock 1996). In this respect, increasing the survival of the second chick may be useful in order to increase the success of the intervention for conservation projects.

Vultures are species with low fecundity rates ( 1 or 2 eggs per clutch) and delayed maturity (Mundy et al. 1992). One of the species considered to be an obligate brood reducer is the endangered Bearded Vulture Gypaetus barbatus (Simmons 1988, Margalida et al. 2004). This 
vulture is considered endangered in the European Union with less than 150 territories. In Spain, one of the management measures proposed for the conservation of this species is to increase the stock of captive breeders through management techniques that include boosting productivity by removing the second chick (MMA 2002).

In this paper we focus on this management action based on the description of sibling aggression behaviour, the preliminary results on the influence of supplementary feeding and the first rescue of a second-hatched chick in order to establish guidelines for future management of conservation projects.

\section{Methods}

The study species

The Bearded Vulture is a large, territorial bird of prey with a long lifespan, which nests on rocky cliffs (Margalida and Bertran 2000a). Although the diet of the species is largely based on bone remains of domestic and wild ungulates, it also feeds on dead animals such as birds, small carnivores or micro-mammals (Margalida et al. 2009).

\section{Monitoring system}

In 2000 we designed a system using solar-powered video cameras that transmitted images via telemetry to a monitor to study the breeding biology of Bearded Vultures (Margalida et al. 2005, 2006). From 2000-2008 a total of 9 Bearded Vulture territories were equipped with video cameras. One of the most important objectives of the use of video cameras was to document sibling aggression to establish a protocol for rescuing the second egg or chick to improve productivity and increase captive stock for reintroduction projects (Margalida et al. 2004). Nevertheless, breeding failures, technical problems and simple clutches limited the data obtained. Thus, this study has focused on data obtained in nests with double clutches.

The camera system included transmitting equipment (a video camera and a transmitting antenna, powered by a solar panel or a wind-powered battery charger, and a battery) and receiving equipment (a receiving antenna and a video recorder with a colour monitor) (for details see Margalida et al. 2006).

\section{Supplementary feeding}

During 2004-2008 we experimentally supplemented three pairs (E, F and G) with food to determine whether it influenced the survival of second-hatched chicks. The other nests (B and D) were not supplemented and considered as controls. Prey items were delivered from the hatching of the first chick until the death of the second chick and were placed at the top of the cliff on which the nest was situated. Food items were delivered every two days and consisted of the remains of rabbits (2-3 kg per delivery) placed $<100 \mathrm{~m}$ from the nest. Generally the pairs found the remains and delivered them to the nest the same day.

\section{Data collection and analyses}

Observations were made from dawn to dusk. In the three focal pairs in which we obtained most data, Nest $\mathrm{B}$ was observed for a total of $120 \mathrm{~h}$ (mean $\pm \mathrm{SD}=9.9 \pm 1.3 \mathrm{~h}$ per day), Nest D $121.5 \mathrm{~h}$

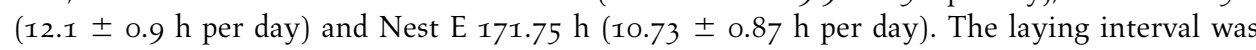
defined as the number of days that elapsed between the laying of the first and second eggs. Hatching asynchrony was defined as the time elapsed between the hatching of the first and second eggs. After hatching we video-recorded all feeding bouts and aggression between siblings (older 
chick or $C_{1}$ and younger chick or $C_{2}$ ). We calculated the following variables: number of prey items delivered per hour between the hatching of the first egg and the death of the second chick, the number of items swallowed by $C_{1}$ during each feeding bout per day, the number of items swallowed by $\mathrm{C}_{2}$ during each feeding bout per day the day after hatching when the first sibling aggression episode was observed, the number of attacks during sibling aggression initiated by $\mathrm{C}_{1}$, and the number of attacks initiated by $\mathrm{C}_{2}$.

\section{Results}

\section{Survival of the second chick and influence of supplementary feeding}

The age of the second chick when it died varied between 4 and 9 days (mean $=6.8 \pm 2.3, n=5$, Table 1). The two second-hatched chicks that survived for the shortest time (4 and 5 days) corresponded to two of the non-supplemented nests. Sibling aggression began on day 1 in nonsupplemented nests $(n=3)$, while aggression was delayed until days 2 and 3 after hatching in food-supplemented ones $(n=3)$ (see Table 1 ). When we compared the prey items delivered per hour and the items ingested/day (as a surrogate of food biomass available in the nest), similar results were obtained among food-supplemented and non-supplemented nests (Table 1 ). With respect to the items ingested by $\mathrm{C}_{2}$, in Nest $\mathrm{B}_{2}$ ingested only five items, in Nest $\mathrm{D}_{14}$, and in Nest $\mathrm{E} 160$ items. When we compared the average number of items ingested per day, significant differences were found, with the nest that was supplemented with food being where $\mathrm{C}_{2}$ ingested significantly more food $\left(F_{2,20}=6.70, P=0.007\right)$. However, no significant differences were found among nests taking into account the average number of attacks per day received by $\mathrm{C}_{2}\left(F_{2,20}=\right.$ $0.70, P=0.51)$ and the number of attacks per day initiated by $\mathrm{C}_{2}\left(F_{2,20}=0.94, P=0.41\right)$.

\section{Procedure to rescue a second-hatched chick}

On 15 February 2008 we applied for the first time the rescue of a second chick with an age of 5 days (Nest G). The time from the top of the cliff to the nest was 1 h 8 min. The first chick was fed before leaving the nest and several prey items were delivered to the nest. The time at in the nest during the rescue was $17 \mathrm{~min}$. The two climbers left the cliff at $12.30 \mathrm{~h}$ carrying the second chick in a container lined with wool. It weighed $124 \mathrm{~g}$ and was found to have no serious injures. It demanded food normally and was fed. The second chick was fed at the top of the cliff and transported by a veterinarian to a recovery centre. After the climbers left the cliff, the adult entered the nest at $13.49 \mathrm{~h}$. The monitoring showed normal behaviour in the adults, and on Io June 2008 the chick (CI) left the nest successfully. The second chick currently forms part of the European Endangered Species Programme's (EEP) captive breeding network.

\section{Discussion}

These are the first data and the application of brood mate manipulation on an obligate brood reducer and an endangered species that is very sensitive to human disturbance (Arroyo and Razin 2005). The survival age of second-hatched chicks in the Pyrenean Bearded Vulture ranges between 4 and 9 days (Margalida et al. 2004). In the only case of sibling aggression documented in Crete, the second chick died at the age of 5 days, suggesting that the age for the rescue of the second chick should be established "at 1-2 days old, preferably the day following hatching when it is in its best physical condition" (Grivas et al. 2009). However our results suggest that the recommended age for the intervention ranges between 3-6 days, with 4-5 days probably being the optimal age for the rescue. In this sense, delaying the rescue as much as possible allows the first-hatched chick to be older and so increase its chances of survival during the time that it remains unattended (at this age the low temperatures oblige the adult to brood the chicks continuously, Margalida and Bertran 20oob). On the other hand, the second chick can remain in 
Table 1. Egg-laying asynchrony, hatching asynchrony and survival age of the second chick (in days) in the Bearded Vulture in the Pyrenees, in accordance with whether pairs were supplied with food or not.

\begin{tabular}{|c|c|c|c|c|c|c|c|c|c|c|}
\hline Nest-year & $\begin{array}{l}\text { Egg-laying } \\
\text { asynchrony }\end{array}$ & $\begin{array}{l}\text { Hatching } \\
\text { asynchrony }\end{array}$ & $\begin{array}{l}\text { First aggressions } \\
\text { after hatching }\end{array}$ & $\begin{array}{l}\text { Age at } \\
\text { death } \mathrm{C}_{2}\end{array}$ & $\begin{array}{l}\text { Supplementary } \\
\text { feeding }\end{array}$ & $\begin{array}{l}\text { Prey items } \\
\text { delivered } \mathrm{hr}^{-1} \\
\text { until the } \\
\text { death of } \mathrm{C}_{2}\end{array}$ & $\begin{array}{l}\text { Daily average of } \\
\text { items ingested } \\
\text { by } C_{I}\end{array}$ & $\begin{array}{l}\text { Daily average of } \\
\text { items ingested } \\
\text { by } \mathrm{C}_{2}\end{array}$ & $\begin{array}{l}\text { Average attacks } \\
\text { received } \mathrm{C}_{2} \\
\text { per day }\end{array}$ & $\begin{array}{l}\text { Average attacks } \\
\text { initiated } \\
\mathrm{C}_{2} \\
\text { per day }\end{array}$ \\
\hline A-2001 & 6 & - & - & - & - & - & & - & - & - \\
\hline A-2000 & - & 6 & - & - & - & - & & - & - & - \\
\hline B-2001 & 7 & 8 & 1 & 4 & None & $0.17 \pm 0.01$ & $75.92 \pm 20.81$ & $\begin{array}{l}1 \pm 1.41 \\
(5)\end{array}$ & $\begin{array}{l}13.6 \pm 14.36 \\
(68)\end{array}$ & $\begin{array}{l}0.6 \pm 0.89 \\
(3)\end{array}$ \\
\hline C-1995 & - & 7 & - & - & - & - & & - & & \\
\hline D-2003 & 6 & 5 & 1 & 7 & None* & $0.32 \pm 0.01$ & $157.41 \pm 21.45$ & $\begin{array}{l}2.33 \pm 1.86 \\
(14)\end{array}$ & $\begin{array}{l}23.17 \pm 20.60 \\
(139)\end{array}$ & $\begin{array}{l}2.67 \pm 2.80 \\
(16)\end{array}$ \\
\hline D-2002 & 6 & 7 & 1 & 5 & None & & & - & - & - \\
\hline E-2002 & 5 & - & - & - & - & - & & - & - & - \\
\hline F-2003 & 6 & - & - & - & - & - & & - & - & - \\
\hline E-2004 & 6 & 6 & 3 & 9 & Yes & $0.21 \pm 0.04$ & $147.2 \pm 19.18$ & $\begin{array}{l}16 \pm 12.53 \\
(160)\end{array}$ & $\begin{array}{l}13.5 \pm 15.43 \\
(135)\end{array}$ & $\begin{array}{l}2.9 \pm 3.93 \\
(29)\end{array}$ \\
\hline F-2005 & - & 6 & 2 & 9 & Yes & - & & - & - & - \\
\hline G-2008 & - & - & 2 & $\begin{array}{l}\text { Rescued } \\
\text { when } \\
5 \text { days old }\end{array}$ & Yes & - & & - & - & - \\
\hline
\end{tabular}

*Supplementary food only was delivered for one day. 
good condition for at least 2-3 days. Data obtained from captive birds suggest that on the first day after hatching the weight of hand-reared Bearded Vultures decreases 3.86\%, increasing progressively thereafter (second day: $2.06 \%$, third: 6.75\%, fourth: $7.99 \%$ ) (Frey et al. 1995). Thus, taking into account the loss of weight during the first day after hatching, the length of survival (4-9 days) and the fact that no serious injures were observed after siblicidal conflicts, it seems more appropriate not to start the intervention during the first two days of life of secondhatched chicks. The intervention should take into account the onset of aggressive behaviour, the physical condition of the second chick (i.e., if it has access to food and ingests items occasionally), the weather conditions (e.g., low temperatures may affect the survival of the $\mathrm{C}_{I}$ if the adults take a long time to return to the nest) and other factors such as the presence of potential predators like the Raven Corvus corax in nesting areas (see Bertran and Margalida 2004).

Our results suggest that the survival age of second-hatched chicks could be related to several variables. Firstly, the hatching asynchrony facilitates the death of the smallest chick (Amundsen and Slagsvold 1996). In the case of the Bearded Vulture, the hatching asynchrony of 5-8 days is much longer that the 3-4 days observed in other obligate siblicidal raptors (Edwards and Collopy 1983) and probably a reduced asynchrony could increase the time survival of $\mathrm{C}_{2}$. Secondly, the artificial food supplied could increase the items ingested by $\mathrm{C}_{2}$, thereby increasing its survival. Although our sample size is limited, in several facultatively siblicidal raptors, observations are consistent with the hypothesis that siblicide is influenced by food resources (Estes et al. 1999, Margalida et al. 2007). In addition, in obligate siblicidal species, aggression of senior brood mates was proven to be flexible and food sensitive (Osorno and Drummond 2003). In this sense, our preliminary results suggest that in the Bearded Vulture the nests with faster mortality ( 4 and 5 days) were both non-supplemented. In addition, nests supplied with food delayed aggression until the second or third day. This suggests that food supplied indirectly could delay aggressiveness between broods, allowing $\mathrm{C}_{2}$ to have a better physical condition and possibilities of accessing food. However, one confounding factor may be hatching asynchrony that promotes the establishment of size hierarchies in the chicks (Stokland and Amundsen 1988), facilitating the aggression among siblings and brood reduction.

\section{Conservation implications}

Although the risks of intervention in an endangered species such as the Bearded Vulture are obvious, our experience suggests that this conservation tool could be applied to increase captive stock for future reintroduction projects. In addition, small populations such as in Corsica or Crete could increase productivity by applying this method. This case study in the Bearded Vulture may allow other researchers and managers to apply similar procedures adapted to the ecological characteristics of other siblicidal species. In this respect, the use of video cameras and probably the application of supplementary feeding could be necessary to increase the success of this intervention.

\section{Acknowledgements}

We thank J. Canut, E. Edo, J. Martín, R. Pelayo, P. Romero, A. Ruiz, E. Vega and specially M. Arilla, C. Barri, E. Bragulat, X. Joanola, A. Llopis, L.M. Martin, J. Mayural, A. Monsó, J. Palomares (Unitat de Suport de Muntanya of the Cos d'Agents Rurals of Generalitat de Catalunya) for their help during field work. Comments of B. E. Arroyo, G. R. Bortolotti and J. L. Tella improved this manuscript. This study was founded by Dirección General para la Biodiversidad of Ministerio de Medio Ambiente and Departament de Medi Ambient i Habitatge of Generalitat de Catalunya. 


\section{References}

Amundsen, T. and Slagsvold, T. (1996) Lack's brood reduction hypothesis and avian hatching asynchrony: what's next? Oikos 76: 613-620.

Anderson, D. J. (1990) Evolution of obligate siblicide in boobies. I. A test of the insuranceegg hypothesis. Am. Nat. 135: 334-350.

Arroyo, B. E. and Razin, M. (2005) Effect of human activities on bearded vulture behaviour and breeding success in the French Pyrenees. Biol. Conserv. 128: 276-284.

Bertran, J. and Margalida, A. (2004) Interactive behaviour between Bearded Vultures Gypaetus barbatus and common ravens Corvus corax: predation risk and kleptoparasitism. Ardeola 51: 269-274.

Bortolotti, G. R. (1986) Evolution of growth rates in eagles: sibling competition vs. energy considerations. Ecology 67: 182-194.

Cade, T. J. (2000) Progress in translocation of diurnal raptors. Pp. $343-372$ in R. D. Chancellor and B.-U. Meyburg, eds. Raptors at risk. Surrey, BC, Canada: World Working Group on Birds of Prey and Owls/ Hancock House Publishers.

Edwards, T. C. and Collopy, M. W. (1983) Obligate and facultative brood reduction in eagles: an examination of factors that influence fratricide. Auk 100, 630-635.

Estes, W. A., Dewey, S. R. and Kennedy, P. L. (1999) Siblicide at northern Goshawk nests: does food play a role. Wilson Bull. III: $423-436$

Forbes, L. S. and Mock, D. W. (1996) Food, information and avian brood reduction. Ecoscience 3: 45-53

Frey, H., Knotzinger, O. and Llopis Dell, A. (1995) The breeding network: an analysis of the period 1978 to 1995 . Pp. 13-38 in H. Frey, J. Kurzweil and M. Bijleveld, eds. Bearded Vulture annual report 1995. Melk, Austria: Foundation for the Conservation of the Bearded Vulture.

Gargett, V. (1990) The Black Eagle, a study. Johannesburg: Acorn Books.

González, L. M., Margalida, A., Sánchez, R. and Oria, J. (2006) Supplementary feeding as an effective tool for improving breeding success in the Spanish imperial eagle ( $A q$ uila adalberti). Biol. Conserv. 129: 477-486.
Grivas, C., Xirouchakis, S. M., Christodoulou, C., Cárcamo-Aboitiz, B., Georgiakakis, P. and Probonas, M. (2009) An audio-visual nest monitoring system for the study and manipulation of siblicide in Bearded Vultures Gypaetus barbatus on the island of Crete (Greece). J. Ethol. 27: 105-116.

Jones, C. G. (2004) Conservation management of endangered birds. Pp. 269-301 in W. J. Sutherland, I. Newton and R. E. Green, eds. Bird ecology and conservation: a handbook of techniques. Oxford: Oxford University Press.

Kepler, C. B. (1978) Captive propagation of whooping cranes: a behavioural approach. Pp. 231-241 in S. A. Temple, ed. Endangered birds. Management techniques for preserving threatened species. Wisconsin: University of Wisconsin Press.

Margalida, A. and Bertran, J. (200oa) Nestbuilding behaviour of the Bearded Vulture (Gypaetus barbatus). Ardea 88: 259-264

Margalida, A. and Bertran, J. (200ob) Breeding behaviour of the Bearded Vulture (Gypaetus barbatus): minimal sexual differences in parental activities. Ibis 142: 225-234.

Margalida, A., Bertran, J. and Heredia, R. (2009) Diet and food preferences of the endangered Bearded Vulture Gypaetus barbatus: a basis for their conservation. Ibis 151: 235-243.

Margalida, A., Boudet, J. and Bertran, J. (2005) Assessing the diet of nestling Bearded Vultures: a comparison between direct observation methods. J. Field Ornithol. 76: 40-45.

Margalida, A., Boudet, J., Bertran, J. and Heredia, R. (2004) Hatching asynchrony, sibling aggression and cannibalism in the Bearded Vulture Gypaetus barbatus. Ibis 146: 386-393.

Margalida, A., Ecolan, S., Boudet, J., Bertran, J., Martinez, J.-M. and Heredia, R. (2006) A solar-powered transmitting video camera for monitoring cliff-nesting raptors. J. Field Ornithol. 77: 7-12.

Margalida, A., González, L. M., Sánchez, R., Oria, J., Prada, L., Caldera, J., Aranda, A., 
Molina, J. I. (2007) A long-term scale study of the breeding biology of the Spanish Imperial eagle Aquila adalberti. J. Ornithol. 148: 309-322.

Meyburg, B.-U. (1978) Sibling aggression and cross-fostering of eagles. Pp. 195-200 in S. A. Temple, ed. Endangered birds. Management techniques for preserving threatened species. Wisconsin: University of Wisconsin Press, Wisconsin.

MMA (2002) Estrategia para la conservación del Quebrantahuesos (Gypaetus barbatus) en España. Madrid: Dirección General para la Conservación de la Naturaleza.

Mundy, P., Butchart, S., Ledger, D. and Piper, S. 1992. The vultures of Africa. San Diego, CA: Academic Press.
Osorno, J. L. and Drummond, H. (2003) Is obligate siblicidal aggression food sensitive? Behav. Ecol. Sociobiol. 54: 547554.

Simmons, R. E. (1988). Offspring quality and the evolution of cainism. Ibis 130: 339-357.

Stokland, J. N. and Amundsen, T. (1988) Initial size hierarchy in broods of the shag: relative significance of egg size and hatching asynchrony. Auk 105: 308315.

Watson, R. T., Thomsett, S., O'Daniel, D. and Lewis, R. (1996) Breeding, growth, development and management of the Madagascar fish-eagle (Haliaeetus vociferoides). J. Raptor Res. 30: 21-27.

\section{ANTONI MARGALIDA*, JOAN BERTRAN}

Bearded Vulture Study and Protection Group. Apdo. 43. E-25520 El Pont de Suert (Lleida), Spain.

\section{DIEGO GARCÍA}

Departament de Medi Ambient i Habitatge, Generalitat de Catalunya, C/ Dr Roux 80, 08017, Barcelona, Spain.

\section{RAFAEL HEREDIA}

Camino del Túnel, 198, 33203 Somió, Gijón, Spain.

*Author for correspondence; e-mail: margalida@inf.entorno.es

Received I October 2008; revision accepted 12 March 2009; Published online 16 October 2009 